\title{
Challenging the catechism of therapeutics for chronic neuropathic pain: targeting CaV2.2 interactions with CRMP2 peptides
}

\author{
Polina Feldman ${ }^{a}$ and Rajesh Khanna ${ }^{a, b, c, d, *}$ \\ aSophia Therapeutics LLC, 351 West 10th Street, Indianapolis, IN 46202, USA \\ bDepartment of Pharmacology and Toxicology, 635 Barnhill Drive, Indianapolis, IN 46202, USA \\ 'Department of Biochemistry and Molecular Biology, 635 Barnhill Drive, Indianapolis, IN 46202 , \\ USA \\ dProgram in Medical Neurosciences, Paul and Carole Stark Neurosciences Research Institute, \\ 950 West Walnut Street, Indianapolis, IN 46202, USA
}

\begin{abstract}
Chronic neuropathic pain management is a worldwide concern. Pharmaceutical companies globally have historically targeted ion channels as the therapeutic catechism with many blockbuster successes. Remarkably, no new pain therapeutic has been approved by European or American regulatory agencies over the last decade. This article will provide an overview of an alternative approach to ion channel drug discovery: targeting regulators of ion channels, specifically focusing on voltage-gated calcium channels. We will highlight the discovery of an anti-nociceptive peptide derived from a novel calcium channel interacting partner - the collapsin response mediator protein 2 (CRMP2). In vivo administration of this peptide reduces pain behavior in a number of models of neuropathic pain without affecting sympathetic-associated cardiovascular activity, memory retrieval, sensorimotor function, or depression. A CRMP2derived peptide analgesic, with restricted access to the CNS, represents a completely novel approach to the treatment of severe pain with an improved safety profile. As peptides now represent one of the fastest growing classes of new drugs, it is expected that peptide targeting of protein interactions within the calcium channel complex may be a paradigm shift in ion channel drug discovery.
\end{abstract}

\section{Introduction}

The Institute of Medicine of the National Academies in 2011 estimated that 116 million adults in the USA ( 1 in 3) suffer from chronic pain every year [50]. Chronic pain costs the nation up to $\$ 635$ billion each year in medical treatment and lost productivity. Although some chronic pain conditions can be treated adequately with existing drugs, a large number of patients fail to achieve adequate pain relief, even with polypharmacy. Furthermore, currently available opioid pain therapies, which are generally only partially effective, are

(C) 2013 Elsevier Ireland Ltd. All rights reserved.

*Corresponding author:950 West Walnut Street, R2-Room 478, Indianapolis, Indiana 46202, USA Office phone: (317) 278-6531; Fax: (317) 278-5849; khanna5@iu.edu.

Publisher's Disclaimer: This is a PDF file of an unedited manuscript that has been accepted for publication. As a service to our customers we are providing this early version of the manuscript. The manuscript will undergo copyediting, typesetting, and review of the resulting proof before it is published in its final citable form. Please note that during the production process errors may be discovered which could affect the content, and all legal disclaimers that apply to the journal pertain. 
often associated with many side effects that limit their clinical efficacy, including tolerance and addiction. Hence, new research and therapies are critically needed to decipher pain mechanisms and open new avenues for specific and more effective treatments. Several excellent reviews describing the roles of voltage-gated calcium [94, 100, 113, 115] and sodium $[36,37]$ channels in pain have appeared in the literature; thus, in this review, we will focus on a new peptide-based therapeutic approach for chronic pain.

\section{Rationale for targeting calcium channels for pain research}

$\mathrm{N}$-type voltage-gated calcium channels (CaV2.2) are multiprotein complexes comprised of a pore-forming $\alpha$-subunits and auxiliary $\alpha 2 / \delta, \beta$, and $\gamma$ subunits [39, 102]. CaV2.2 channels are localized to primary afferent terminals in laminae 1 and 2 of the dorsal horn [108] where their activation results in the influx of calcium and release of neurotransmitters such as glutamate, substance $\mathrm{P}$, and calcitonin gene related peptide (CGRP). Following discovery of CaV2.2-specific conotoxins, the biological role of this channel was evaluated in animals through the use of isoform-specific inhibitors. Specific interest in the role of CaV2.2 in sensation arose from the observation that omega-conotoxin ( $\omega$-CTX) was able to block transmitter release from sensory neurons and spinal nerve terminals [46, 61]. CaV2.2 channels are also critical for pain transduction as block of these channels relieves hyperalgesia [8, 47, 56], mice lacking CaV2.2 show an increased threshold for pain [84], and expression of CaV2.2 is upregulated following a chronic constrictive nerve injury [34]. Spinal administration of CaV2.2 blocking peptides has been shown to ameliorate painful behavior in rodent models of neuropathic and inflammatory pain [87]. Interestingly, several CNS effects were also observed in the mice including; decreased anxiety behavior, changes in vigilance, and enhanced aggressive behavior [15, 55, 84]. The importance of CaV2.2 in pain is further underscored by the demonstration of a naturally occurring alternative splice form of CaV2.2 (i.e. exon 37a) in small-diameter nociceptive neurons [14] which are critical for basal thermal nociception, and thermal and mechanical hyperalgesia [8]. The role of CaV2.2 in neurotransmitter release and pain sensation is further reinforced by studies demonstrating that analgesic opioids and adrenergic agonists inhibit CaV2.2 [89]. In sum, by virtue of their ability to control the regulated release of neurotransmitters from nociceptive afferents, $\mathrm{N}$-type $\mathrm{Ca}^{2+}$ channels are a prime target for the development of novel analgesics $[86,94,113,115]$.

\section{Examples, limitations, and pipeline of CaV2.2-targeted drugs}

Several subtypes of neuronal voltage-gated calcium channels are expressed in the nociceptive pathway and are crucial for shaping action potentials and controlling cellular excitability and synaptic transmission [115]. Recently, Ziconitide (trade-name Prialt ${ }^{\text {) }}$ ) was approved by the Food and Drug Administration (FDA) for the treatment of severe pain that was refractory to other therapies [38]. This drug is a synthetic version of the naturally occurring cone snail toxin $\mu$-conotoxin MVIIA and is a highly potent and selective peptide blocker of CaV2.2, validating $\mathrm{N}$-type calcium channels as a promising target of novel analgesics. However, due to the profound side effects and a lack of efficacy when delivered by more common routes (i.e. intravenous or oral), the use of Prialt ${ }^{\circledR}$ is limited to intrathecal pump route of administration, i.e. direct application to the spinal synapse between sensory neurons and spinal neurons. That intrathecal application is required and sufficient for analgesia also supports the notion that presynaptic blockade of CaV2.2 is responsible for targeting pain. The use of Prialt ${ }^{\circledR}$ via this route is not without complications as the intrathecal route of administration is by far the most expensive and invasive method of drug delivery. Many side effects are accompanied by the use of the drug that often manifest as confusion, depression, hallucinations, decreased alertness, somnolence, orthostatic hypotension and nausea $[79,85,92,99]$. Prialt ${ }^{\circledR}$ is also contraindicated in patients with pre- 
existing mental disorders due to thoughts of suicide and worsening depression or paranoia [62]. Subsequently, Prialt ${ }^{\circledR}$ therapy in practice for neuropathic pain treatment, is warranted for relatively few patients who are intolerant or refractory to other treatments [109], such as systemic analgesics, adjunctive therapies or intrathecal morphine $[6,76,77]$. Prialt $®$ is a state-independent CaV2.2 blocker and therefore inhibits the activity of the channel in both the hyperpolarized state (closed) and the depolarized state (open or inactivated) [42]. Thus, the side effects presumably occur through a non-selective blockade of $\mathrm{N}$-channels in all tissues $[1,98]$.

Despite the shortcomings of Prialt@, blockade of the presynaptic, CaV2.2 and its affiliated subunits remains an important therapeutic target for a number of chronic pain conditions $[39,94]$. One commonly used drug that targets the a $2 \delta 1$ subunit of CaV2.2 is the antiepileptic drug, gabapentin (Neurotin $\left.{ }^{\circledR}\right)$. Neurotin ${ }^{\circledR}$ is FDA-approved for a number of conditions including postherpetic neuralgia, diabetic neuropathy $[12,33,45,68]$, neuropathic pain $[3,18,88]$, phantom limb pain $[9,16,53,71,83]$, fibromyalgia [116] and trigeminal neuralgia $[67,74]$. Consistent, though less compelling clinical evidence supports its use for a variety of other neuropathic pain syndromes, including cancer pain syndromes, pain associated with HIV infection and chronic back pain. Controlled clinical trials in diabetic neuropathy and postherpetic neuralgia [82] demonstrated that gabapentin at 2400-3600 mg/day has an efficacy similar to the tricyclic antidepressants [2]. Though gabapentin has a favorable pharmacokinetic profile, it is only available in oral form and requires at least three times daily dosing in order to achieve mean plasma levels throughout a 24-hour period to achieve efficacy [13]. However, one benefit of the drug is that, unlike Prialt, it does not require laboratory monitoring [103, 104].

Neurotin ${ }^{\circledR}$ is associated with only moderate to substantial benefits of pain relief in $31-43 \%$ of patients [67]. Adverse events are experienced by about two-thirds of people taking gabapentin, mainly dizziness, somnolence (27\%), dizziness $(24 \%)$, and ataxia (7\%) and it is not an uncommon finding that patients are not able to tolerate dosing in the therapeutic range due to common side effects [67]. Gabapentin was also reported to disrupt the interaction between $a_{2} \delta-1$ and thrombospondins in vitro and, as a result, interferes with synaptogenesis, although it does not affect pre-formed synapses [41], a finding that could encumber prolonged use of this class of drug.

There remains strong interest in the pharmaceutical and academic worlds toward the development of orally acting, state-dependent blockers of CaV2.2. Several research and development groups have made substantial progress in developing small organic molecules targeting 'hot spots' of the N-type calcium channel. One group in particular led, by scientific investigator Terrance P. Snutch, has targeted chemical moieties that possess calcium channel blocking activity, such as the diphenylmethylpiperazine basic skeleton $[17,72,73,114]$. Through extensive structure-activity relationship (SAR) investigations two small organic molecules NP118809 and NP078585 have been discovered and optimized as a N-type calcium channel blockers with good selectivity over L-type calcium channels [114]. In doing so, Snutch and colleagues have gone on to commercialize several of these small molecules selective for N-type or T-type calcium channel blockers, two of which are steadily progressing through the FDA regulatory pathway by Zalicus, Inc, a biopharmaceutical company that discovers and develops novel treatments for patients suffering from pain. Specifically, Zalicus, Inc. is developing an orally available selective N-type calcium channel blocker (Z160) for the treatment of chronic neuropathic pain associated with lumbosacral radiculopathy and post-herpetic neuralgia. Z160 is in currently being tested in Phase II clinical trials (www.zalicus.com). Convergence Pharmaceuticals, LLC has also developed an orally available small molecule (CNV2197944) state-dependent N-type calcium channel blocker for the treatment of neuropathic pain, currently in Phase IIa clinical trials 
(www.convergencepharma.com). Newron Pharmaceuticals SpA is perhaps the furthest along the pipeline, as their small molecule drug Ralfinamide is in Phase IIB/III trials, and is believed to mediate its potent analgesic effect through the inhibition of sodium channels, including $\mathrm{NaV} 1.7$, N-type calcium channels and NMDA receptor for the treatment of lower back pain (www.newron.com). Small molecule equivalents of omega-conotoxin CVID (e.g. AM336/CNSB004/Leconotide), the selective N-type calcium channel blocker, have also been engineered and are being tested in early stage preclinical studies for pain associated with diabetes and cancer $[58,59,93]$.

In addition to direct block of calcium channels, targeting of protein-protein interaction (PPI) interfaces within a PPI complex is gaining momentum as a potentially new manner of drug development [27]. Several small molecule PPI inhibitors are currently in clinical development by pharmaceutical companies Abbott, Genentech, Johnson \& Johnson, or Roche; two drugs are already on the market (Tirofiban/Aggrastat ${ }^{\circledR}$ and Maraviroc/ Selzentry ${ }^{\circledR)}$ [44]. The notion of PPIs altering CaV2.2 channel function was proposed almost two decades ago by William Catterall and colleagues who discovered that interruption of the CaV2.2-syntaxin interaction with SYNaptic Protein INTeraction (synprint) peptides inhibits fast, synchronous transmitter release [66, 80, 90, 91]. Despite this early report, these patented [28] peptides have not advanced further. Additional peptides that attenuate $G$ protein modulation of $\mathrm{Ca}^{2+}$ channels have also been reported and may be of use in probing calcium channel mediated presynaptic mechanisms [25, 26]; however, none of these peptides have been translated beyond. As will be described in the following sections, Sophia Therapeutics, LLC in collaboration with Indiana University has developed a novel peptide platform that target $\mathrm{CaV} 2.2$ by modulating channel activity through protein/protein interactions for the treatment of neuropathic pain. Sophia Therapeutics is currently performing preclinical in vivo studies and is actively seeking funding and partnership opportunities to move the project into Phase I clinical trials.

\section{Discovery of CRMP2, a novel regulator of $\mathrm{CaV2.2}$}

Alternative strategies that target proteins interacting with calcium channels represent an emerging theme in drug discovery for treatment of clinical neuropathic pain. A proteomic screen identified the collapsin response mediator protein 2 (CRMP2) as a putative interacting partner of CaV2.2 [54, 69]. Enriched at functional release sites, CaV2.2 forms part of a large macromolecular complex, which facilitates efficient neurotransmitter release. Identification and analyses of a litany of protein-protein interactions within the nerve terminal have demonstrated a functional coupling between presynaptic $\mathrm{Ca}^{2+}$ channels and the transmitter release machinery $[31,35,57,95]$. Although neurotransmission was not affected in CRMP1 knockout mice [97], long-term potentiation, spatial learning and memory were affected in both CRMP1 and CRMP3 knockout mice [78, 97], suggesting a possible role for CRMPs in neurotransmission as well as synaptogenesis. As potential binding partners, CRMPs could affect neurotransmission by either a physical interaction with the synaptic machinery or CaV2.2 itself.

Our study showed that CRMP2 is part of the CaV2.2 proteome [22, 32, 54].

Immunocytochemistry revealed a strong colocalization between CRMP2 and CaV2.2 within hippocampal neurons that was supported by reciprocal co-immunoprecipitation of the two proteins. CRMP2 localized to both extrasynaptic and synaptic fractions, suggesting that it may traffic CaV2.2 within these regions (Figure 1). CRMP2 was present in both cytosolic and membrane fractions. CRMP2 was found to localize to the soma, dendrites, and axons and therefore may interact with $\mathrm{CaV} 2.2$ in any of these regions. Traditional in vitro binding experiments [22] and isothermal titration calorimetric analyses (Khanna, M. and Khanna, R.; unpublished data) mapped the interaction to two domains within the cytoplasmic loops of 
CaV2.2 [22]. The CRMP2-CaV2.2 interaction was dynamic as potassium chloride-induced depolarization led to an increase in the interaction. Functionally, the interactions led to an increased cell-surface expression of CaV2.2 that caused an increase in CaV2.2 current density in hippocampal neurons. This CRMP-2-mediated increase in $\mathrm{Ca}^{2+}$ influx translated into an increase in the release of excitatory neurotransmitter glutamate; toxin block of CaV2.2 eliminated this increase. CRMP2 overexpression also increased stimulated release of CGRP from dorsal root ganglia (DRG) [32]. Furthermore, knockdown of CRMP2 dramatically reduces $\mathrm{Ca}^{2+}$ currents and transmitter release [32]. These findings suggested that the biochemical interaction between CRMP2 and CaV2.2 was required for proper channel trafficking and function.

The strong effect of CRMP2 knockdown on $\mathrm{Ca}^{2+}$ currents in neurons suggested that CRMP2 is necessary for CaV2.2 function. Of significant interest, CaV2.2 current is observed in heterologous systems despite limited CRMP2 expression in these cells, which suggests that rather than directly enhancing CaV2.2 surface expression, CRMP2 may be disinhibiting a negative regulator of CaV2.2 trafficking. This negative regulator would likely be neuron specific, as CRMP2 expression appears to enhance surface expression in neurons, but not in heterologous systems (Priest and Khanna, personal communication). The negative regulation may also represent a channel-recycling pathway, which, without CRMP2, may lead to a majority of channels leaving the membrane and being degraded. As CRMP2 binds to the I-II loop, which has been shown to be an important region for proteasome regulation of CaV2.2, this could be a possible mechanism CRMP2's regulation of CaV2.2 [106]. Assuming that CRMP2 is responsible for overcoming neuronal specific negative regulators of $\mathrm{CaV} 2.2$ would also suggest a mechanism distinct from the other CaV2.2 subunits. Future work will be necessary to further explore the precise mechanism of CRMP2's regulation of CaV2.2.

\section{Design, mechanism of action, and characterization of a CRMP2 peptide as anti-nociceptive}

Having established CRMP2 as a bona fide regulator of CaV2.2 function, we reasoned that disruption of this biochemical and functional interaction may not only lead to the development of a useful tool for studying CaV2.2 channel trafficking but also may yield a potential therapeutic for pain as suppression of $\mathrm{CaV} 2.2$ channel activity had previously been reported to be anti-nociceptive [113]. Our initial mapping of the CaV2.2:CRMP2 interaction had identified a surface-exposed region in CRMP2, which we designated calcium channel binding domain 3 (CBD3) [22]. Further mapping of CaV2.2 binding to overlapping peptides encompassing the full length of CRMP2 yielded four peptides with significant binding to CaV2.2 [21]. Remarkably, of these four, the CBD3 peptide identified in our earlier study displayed the highest binding to $\mathrm{CaV} 2.2$. The sequence of this fifteen amino acid peptide is relatively conserved amongst CRMPs 1, 3, 4 and 5 with CRMP3 displaying the highest homology (12 of 15 residues are identical). Interestingly, the CBD3 peptide sequence is completely conserved from humans to zebrafish. The CBD3 peptide bound to immobilized loop 1 and the distal part of the carboxyl terminus of CaV2.2 and in a concentrationdependent fashion, blocked the interaction between recombinantly purified CRMP2 and loop regions of $\mathrm{CaV} 2.2$, between full-length native $\mathrm{CaV} 2.2$ and recombinantly purified CRMP2, demonstrating usefulness as a tool for interrupting the interaction between this protein complex. Tubulin-CRMP2 interaction or the CaV2.2-syntaxin interactions were not affected by CBD3, demonstrating specificity. CBD3 appears to have both an acute as well as a long-term effect on CaV2.2 function. When introduced into heterologous cells, the CBD3 peptide reduced calcium currents likely by preventing surface trafficking of CaV2.2 or increasing CaV2.2 internalization. When CBD3 was expressed in hippocampal neurons, it 
antagonized CRMP2-induced enhancement of $\mathrm{Ca}^{2+}$ channel currents. As CBD3 disrupts the interaction between CRMP2 and CaV2.2, this supports the conclusion that the interaction between CRMP2 and CaV2.2 is likely responsible for the observed increase in $\mathrm{Ca}^{2+}$ currents.

Subsequent creation of TAT-CBD3 (tagged with the HIV-1 transactivator of transcription (TAT) cell penetrating motif) allowed evaluation of this peptide directly in cells as well as in animal models of pain. TAT-CBD3 peptide interfered with CRMP2-CaV2.2 interactions resulting in acute inhibition of CaV2.2 currents in sensory and hippocampal neurons; acute inhibition of frequency of spontaneous excitatory postsynaptic currents (sEPSCs) in spinal cord slices as well as layer $\mathrm{V}$ pyramidal neurons suggesting reduction in probability of glutamate release from stimulated presynaptic terminals; and inhibition of evoked calcitonin gene-related peptide (CGRP) in sensory neurons in culture (acute and long-term inhibition observed) and in spinal cord slices.

Our results converged on the possibility that TAT-CBD3 might act as a novel antagonist of $\mathrm{CaV} 2.2$ function prompting us to investigate its usefulness as a therapeutic for pain using an in vivo model of hypersensitivity. TAT-CBD3 was tested in a battery of behavioral assays including formalin-induced nocifensive behavior, capsaicin-induced nocifensive behavior, and chronic neuropathic models including distal sensory polyneuropathy induced by antiretroviral drugs, lysophosphotidylcholine-induced sciatic nerve focal demyelination (LPC), and traumatic tibial nerve injury model. In all of these models, TAT-CBD3 reduced nocifensive behaviors or induced reversal of hypersensitivity. Notably, these effects were observed with systemic injections of TAT-CBD3 in stark contrast to the intrathecal route of delivery espoused for Prialt $\circledR_{\text {. }}$

Importantly, in a further string of rodent behavioral tests to examine off-target effects, TATCBD3 was mildly anxiolytic without affecting memory retrieval, sensorimotor function, or depression at doses at least 50 fold higher than needed to achieve anti-nociception.

Sympathetic-associated cardiovascular activity was also not affected by TAT-CBD3 [110]. Thus, peptide analgesics, such as TAT-CBD3, with restricted access to the CNS represent a completely novel approach to the treatment of severe pain with a likely improved safety profile.

\section{CRMP2 peptides: good, better, best?}

While we have documented great success with TAT-CBD3, challenges remain including the transiency ( $\leqslant$ hours) of pain reversal with TAT-CBD3 [21], the lack of efficacy in the tibial nerve injury model of persistent neuropathic pain [110], coupled with lack of knowledge of the time course (i.e., pharmacokinetics/bioavailability) of TAT-CBD3's action, additional possible targets and a safety profile have not been fully investigated. In an effort to increase TAT-CBD3's duration of action and utility in a broader range of neuropathic conditions, we have converged our initial efforts on optimizing the CBD3 platform by selected single site mutagenesis and using alternative cell penetrating motifs.

To address the first issue, a peptide array harboring systematic amino acid scans of the CBD3 coupled with a Far-Western approach identified three peptides with point mutations at positions $6(\mathrm{~A} 6 \mathrm{~K}), 9(\mathrm{R} 9 \mathrm{~L})$ and $14(\mathrm{G} 14 \mathrm{~F})$ with greater binding to $\mathrm{Ca}^{2+}$ channels than the parent CBD3 peptide [75]. One of these peptides, TAT-CBD3-A6K, was modeled as an ahelix and molecular dynamics (MD) simulations were performed to explore atomistic flexibility of wild type and A6K mutant peptides in solution. This analysis showed that like the wild type peptide, the $\mathrm{C}$-terminus residues are less stable than $\mathrm{N}$-terminus residues, which consistently maintain an a-helical structure throughout the MD simulation. Increased 
conformational change of the mutant peptide may result in greater efficacy for this peptide. Greater conformational change suggests that the peptide may sample alternative conformational states that are more prone to bind to the calcium channel and inhibit its interaction with CRMP2. The wild type peptide appears more prone to undergo structural changes that are not seen in the A6K mutant simulations. Based on these structural predictions, we tested the mechanism of action and efficacy of TAT-CBD3-A6K and found that (i) this peptide exhibited greater anti-nociception in a rodent model of AIDS therapyinduced peripheral neuropathy when compared to the parent TAT-CBD3 peptide; (ii) intraperitoneal administration of TAT-CBD3A6K produced none of the minor side effects (i.e. tail kinking, body contortion) observed with the parent peptide; (iii) excitability of dissociated small diameter sensory neurons isolated from rats was also reduced by TATCBD3A6K; and (iv) suppression of excitability may be due to inhibition of T- and R-type $\mathrm{Ca}^{2+}$ channels (Figure 4). These results suggested that structural modifications of the CBD3 scaffold peptide might result in peptides with selectivity against a particular subclass of voltage-gated calcium channels resulting in a multi-pharmacology of action on the target.

To improve CBD3's utility to broader range of neuropathic conditions, CBD3 was grafted to a stretch of nine arginines ((R9)-CBD3); the cell penetrating peptide (CPP) R9 motif was chosen due to its superior cell penetrating abilities [107]: it is the most efficacious of currently known protein transduction domains with at least a 20-fold better penetrability into cells than TAT [107] or other homopolymeric amino acids [65]; it is well tolerated by cells, with low short- and long-term toxicological effects [101]; and its the mechanism of transduction into cells is well understood and involves binding to cell surface heparan sulfate proteoglycans, heparin sulfate-mediated endocytosis into vesicles, release of R9 from heparin sulfate upon cleavage by heparanases, culminating in release of unbound R9 into the cytosol due to vesicular leakage [43]. Three endocytic pathways - macropinocytosis, clathrin-mediated endocytosis and caveolae/lipid-raft-mediated endocytosis - are thought to be involved [40]. Similar to TAT-CBD, the R9-conjugated CBD3 peptide interfered with the CaV2.2-CRMP2 interaction. The interference was specific, as the tubulin-CRMP2 interaction was not disrupted by R9-CBD3. The functional consequence of the disrupted CaV2.2-CRMP2 interaction was a significantly higher extent (i.e. efficacy) of inhibition of calcium influx in sensory neurons. This increased efficacy may possibly contribute to the mechanism of action of this peptide. That R9-CBD3 did not affect $\mathrm{Ca}^{2+}$ influx activated by vanilloid receptor activators resiniferatoxin and capsaicin rules out targeting of these receptors as a potential mechanism of action. These results are entirely consistent with our previous data that showed no effect of TAT-CBD3 on TRPV1 current recordings following capsaicin challenge [21] demonstrating that TAT-CBD3 does not work through direct inhibition of TRPV1 channels. We found that R9-CBD3, like TAT-CBD3 [21], was effective at reversing mechanical hypersensitivity induced by NRTI-associated distal symmetrical polyneuropathy. Importantly, R9-CBD3 reversed mechanical hypersensitivity associated with nerve-injury possibly due to its superior cell transduction attributes [107] (Figure 5).

Future efforts will explore alternative routes of dosing including continuous subcutaneous infusions, intramuscular, sublingual and or oral routes. Clinically, $\sim 2-4$ grams/day of gabapentin are needed to achieve significant reduction in average daily pain intensity scores compared with placebo [13]; but at this dosage the drug is not without significant side effects. Even taking into account allometric scaling, TAT-CBD3 reverses NRTI-induced hypersensitivity at $0.1 \mathrm{mg} / \mathrm{kg}$ compared with $200 \mathrm{mg} / \mathrm{kg}$ of gabapentin needed to achieve similar levels of reversal [21]. One therapeutic challenge for many neurologically acting medications, including TAT-CBD3, is penetration of the blood brain barrier (BBB). The peptide, like Prialt ${ }^{\circledR}$, appears to have a somewhat restricted penetration into the CNS [21], however disruption of the BBB due to direct injury to the spinal cord/brain or disease 
pathologies may allow the peptide to overcome the CNS's physicochemical barriers and alter synapse functioning within higher order systems [20]. More importantly, that peripheral nerve injury or inflammatory pain states may be maintained by CNS gliosis (activated glial cells that release inflammatory mediator) suggests that there could be chronic disruptions in BBB permeability and transport of TAT-CBD3 into the brain. So, despite the relatively restricted penetration across the BBB by TAT-CBD3 it could still have cognitive effects following chronic dosing. Thus, in the future we will also evaluate whether the peptides affect memory and learning, locomotion, social interaction as well as examine histopathological changes in various tissues.

\section{Getting over the "small-molecule fever": peptide market, limitations and optimization}

Peptide based therapeutics for pain and a number of other chronic conditions are on the rise. The number of peptides approved in the past few years falls third in the line with small molecules (45\% of the total) and 'proteins' (24\% of the total). Between 2009-2011, eight peptides were accepted by the FDA, which represents $11 \%$ of the total drugs accepted in this period. The probability of regulatory approval for peptides is over $20 \%$, a rate which is double that of small molecules [60]. Although these peptides have a broad range of structures, size, and complexity, it has not limited their place in the market [5]. The peptide market consists of a relatively small portion of all drug product sales $(\sim 1.5 \%)$. However, peptide drug product sales are increasing with an annual growth of 7.5-10\% [60]. Currently, there are 80 peptides on the market, approximately 200 more in clinical trials and 400 in advanced preclinical states [105], which have demonstrated diverse applications across a number of clinical fields $[11,96]$.

Nature continues to be the main source and best inspiration for the drug discovery process [70]. The clear advantage that drug peptides offer include, a significantly high structural relationship between physiological active parent molecules thereby reducing the risk of offtarget reactions [60] and lack of immunogenicity [64]. Overall, peptides have several advantages as drug; including their high biological activity (given their natural source), high specificity, and low toxicity [5]. Peptides also have the ability to penetrate further into tissues due to their smaller size and require substantially less quantity to activate their target [48]. Compared to small organic molecules, peptides typically offer greater efficacy, selectivity and specificity [49].

In general, it is believed that peptides have several features that prevent active pharmaceutical ingredients; such as, lack of oral bioavailability, low stability under physiological conditions [24, 117], short half-life because of their rapid degradation by proteolytic enzymes of the digestive system, and hydrophobicity (limits their ability to cross physiological barriers) [5]. However, robust peptide chemistry strategies and 'modern' solution organic synthetic chemistry provide for straightforward analog analysis for leadcandidate optimization. The process is quite efficient and economical when compared with small molecules [5].

The half-life of many peptides is primarily dependent on their proteolytic susceptibility. Orally available peptides inevitably battle gram quantities of proteolytic activity in the lumen of the small intestine, which are secreted by the pancreas (e.g. alpha chymotrypsin, trypsin, pancreatic elastase, carboxypeptidases A, etc.). Additionally, the membrane of epithelial cells contains at least 15 peptidases. Other proteolyic sources include lysosomal peptidases and matrix metalloproteinases [105, 112]. Thus, peptide modifications have become necessary strategies to optimize their function as an ideal drug-delivery system and bypass many of the limitations associated with natural peptide kinetics. Chemical 
optimization strategies are based on structure-activity relationship and/or quantitative structure-activity relationship; including cyclization of peptide sequences, substitution with an unnatural amino acids, isosteric amide bond replacement, $\mathrm{N}$-terminal esterification (to enhance plasma stability), peptide conjugation with cell penetrating peptides (i.e. TAT conjugation) just to name a few [4, 105]. For example, Ahrens and co-workers developed 'intelligent peptides' which have smart linkers that increase specificity and blood plasma stability [4]. With the sophistication currently possible in peptide modifications, a promising future for innovative synthetic therapeutic peptides may provide the next generation of pharmaceutical drugs.

\section{Conclusions}

It is clear that CaV2.2 is a nidus for neurotransmitter release $[10,29,30]$ and nociceptive transmission [115]. However, use of CaV2.2 blockers in pain therapeutics (Prialt® or gabapentin) is limited by side-effects resulting from inhibition of the physiological functions of CaV2.2 within the CNS. To circumvent this, we have advanced a strategy for targeting protein interactions that regulate voltage-gated calcium channels as an alternative to direct channel block. In this regard, we identified CRMP2 as a bona fide modulator of $\mathrm{CaV}$ channels[22, 32] with peptides from CRMP2 proving to be anti-nociceptive[21, 51, 81]. Remarkably, interrupting the CaV-CRMP2 interaction with a peptide derived from the $\mathrm{CaV}$ channel reversed pain behavior associated with peripheral neuropathy [111], further validating the CaV-CRMP2 axis as a novel node for development of pain therapeutics. Importantly, targeting channel regulation may potentially avert many of the adverse side effects associated with direct channel block. Indeed, the CRMP2-derived TAT-CBD3 peptide has a problem-free profile with at least a 500-fold therapeutic window [21]. That replacement of a lysine with an alanine residue at the sixth residue of CBD3 allowed the resulting peptide (TAT-CBD3-A6K) to reverse tibial nerve-injury-induced pain which was refractory to TAT-CBD3 [110], as well as bestowed upon the new peptide an ability to block T- and R-type calcium channels (Figure 4) suggests opportunities to tailor peptides for specific pain indications and will be addressed in the future. In conclusion, the TAT-CBD3 peptide is efficacious in both acute and chronic pain models when administered either topically or systemically; CBD3, interfering with the function of CaV2.2, produced analgesic effects in rodents subjected to formalin-induced nocifensive behavior, capsaicininduced nocifensive responses to ocular administration and neurogenic inflammation of the meninges, and reversed the chronic tactile hypernociceptive behavior observed in antiretroviral toxic neuropathy. Collectively, the antinociceptive activity of TAT-CBD3 across a number of pain models suggests that $\mathrm{N}$-type voltage calcium channels on the presynaptic terminals of afferent sensory neurons play a central role in both inflammatory and neuropathic pain behaviors.

\section{Acknowledgments}

The authors thank colleagues at the Stark Neurosciences Research Institute (SNRI), Dr. Joel M. Brittain for fractionation data, Professor Fletcher A. White (Anesthesia, Indiana University) for collaborations on pain models, Dr. May Khanna for isothermal titration calorimetric experiments, and Dr. Joe Trebley at the Indiana University Research and Technology Commercialization for help with Sophia Therapeutics, LLC. This work was supported, in part, by grants from the Indiana Clinical and Translational Sciences Institute (CTSI) funded, in part by a Project Development Team Grant Number (RR025761) from the National Institutes of Health, National Center for Research Resources, Clinical and Translational Sciences Award, the Indiana State Department of Health - Spinal Cord and Brain Injury Fund (A70-9-079138 to R.K.), NIH/NINDS (NS049136-06 to F.A.W.), the Indiana University Biomedical Committee - Research Support Funds (2286501 to R.K), a National Scientist Development from the American Heart Association (SDG5280023 to R.K.), a Research Inventions and Scientific Commercialization grant (to R.K.) from the Indiana CTSI, a Funding Opportunities for Research Commercialization and Economic Success (FORCES) grant initiative from the Indiana CTSI (to R.K.), and the Elwert Award in Medicine to R.K. We also acknowledge funding from the BioCrossroads New Venture competition. R.K. is a shareholder of Sophia Therapeutics, LLC. 


\section{Abbreviations}

CGRP calcitonin gene related peptide

CaV2.2 N-type voltage-gated $\mathrm{Ca}^{2+}$ channel

CBD $\mathrm{Ca}^{2+}$ channel binding domain

CRMP2 collapsin response mediator protein 2

CPP cell penetrating peptide

CNS central nervous system

$\omega$-CTX omega-conotoxin

DIV days in vitro

DRG dorsal root ganglion

PWT paw withdrawal threshold

R9 nona-arginine

ST Sophia Therapeutics

TAT HIV-1 transactivator of transcription domain

TNI tibial nerve injury

CTX conotoxin

LPC lysophosphotidylcholine

sEPSCs spontaneous excitatory postsynaptic currents

NRTI nucleoside reverse transcriptase inhibitor

BBB blood brain barrier

\section{REFERENCES}

[1]. Abbadie C, McManus OB, Sun SY, Bugianesi RM, Dai G, Haedo RJ, Herrington JB, Kaczorowski GJ, Smith MM, Swensen AM, Warren VA, Williams B, Arneric SP, Eduljee C, Snutch TP, Tringham EW, Jochnowitz N, Liang A, Euan MD, McGowan E, Mistry S, White VV, Hoyt SB, London C, Lyons KA, Bunting PB, Volksdorf S, Duffy JL. Analgesic effects of a substituted N-triazole oxindole (TROX-1), a state-dependent, voltage-gated calcium channel 2 blocker. J.Pharmacol.Exp.Ther. 2010; 334:545-555. [PubMed: 20439438]

[2]. Achar A, Chakraborty PP, Bisai S, Biswas A, Guharay T. Comparative study of clinical efficacy of amitriptyline and pregabalin in postherpetic neuralgia. Acta dermatovenerologica Croatica : ADC. 2012; 20:89-94. [PubMed: 22726281]

[3]. Ahn SH, Park HW, Lee BS, Moon HW, Jang SH, Sakong J, Bae JH. Gabapentin effect on neuropathic pain compared among patients with spinal cord injury and different durations of symptoms. Spine. 2003; 28:341-346. discussion 346-347. [PubMed: 12590206]

[4]. Ahrens VM, Bellmann-Sickert K, Beck-Sickinger AG. Peptides and peptide conjugates: therapeutics on the upward path. Future medicinal chemistry. 2012; 4:1567-1586. [PubMed: 22917246]

[5]. Albericio F, Kruger HG. Therapeutic peptides. Future medicinal chemistry. 2012; 4:1527-1531. [PubMed: 22917241]

[6]. Alicino I, Giglio M, Manca F, Bruno F, Puntillo F. Intrathecal combination of ziconotide and morphine for refractory cancer pain: a rapidly acting and effective choice. Pain. 2012; 153:245249. [PubMed: 22082570] 
[7]. Almagor L, Chomsky-Hecht O, Ben-Mocha A, Hendin-Barak D, Dascal N, Hirsch JA. The role of a voltage-dependent $\mathrm{Ca} 2+$ channel intracellular linker: a structure-function analysis. J Neurosci. 2012; 32:7602-7613. [PubMed: 22649239]

[8]. Altier C, Dale CS, Kisilevsky AE, Chapman K, Castiglioni AJ, Matthews EA, Evans RM, Dickenson AH, Lipscombe D, Vergnolle N, Zamponi GW. Differential role of N-type calcium channel splice isoforms in pain. The Journal of neuroscience : the official journal of the Society for Neuroscience. 2007; 27:6363-6373. [PubMed: 17567797]

[9]. Alviar MJ, Hale T, Dungca M. Pharmacologic interventions for treating phantom limb pain. Cochrane Database Syst Rev. 2011 CD006380.

[10]. Atlas D. The Voltage-Gated Calcium Channel Functions as the Molecular Switch of Synaptic Transmission. Annual review of biochemistry. 2013

[11]. Ayoub M, Scheidegger D. Peptide drugs, overcoming the challenges, a growing business. Chim Oggi. 2006; 24:46-48.

[12]. Backonja M, Beydoun A, Edwards KR, Schwartz SL, Fonseca V, Hes M, LaMoreaux L, Garofalo E. Gabapentin for the symptomatic treatment of painful neuropathy in patients with diabetes mellitus: a randomized controlled trial. JAMA : the journal of the American Medical Association. 1998; 280:1831-1836. [PubMed: 9846777]

[13]. Beal B, Moeller-Bertram T, Schilling JM, Wallace MS. Gabapentin for once-daily treatment of post-herpetic neuralgia: a review. Clinical interventions in aging. 2012; 7:249-255. [PubMed: 22866002]

[14]. Bell TJ, Thaler C, Castiglioni AJ, Helton TD, Lipscombe D. Cell-specific alternative splicing increases calcium channel current density in the pain pathway. Neuron. 2004; 41:127-138. [PubMed: 14715140]

[15]. Beuckmann CT, Sinton CM, Miyamoto N, Ino M, Yanagisawa M. N-type calcium channel alpha1B subunit (Cav2.2) knock-out mice display hyperactivity and vigilance state differences. The Journal of neuroscience : the official journal of the Society for Neuroscience. 2003; 23:6793-6797. [PubMed: 12890773]

[16]. Bone M, Critchley P, Buggy DJ. Gabapentin in postamputation phantom limb pain: a randomized, double-blind, placebo-controlled, cross-over study. Regional anesthesia and pain medicine. 2002; 27:481-486. [PubMed: 12373695]

[17]. Borzenko A, Pajouhesh H, Morrison JL, Tringham E, Snutch TP, Schafer LL. Modular, efficient synthesis of asymmetrically substituted piperazine scaffolds as potent calcium channel blockers. Bioorganic \& medicinal chemistry letters. 2013; 23:3257-3261. [PubMed: 23639535]

[18]. Bosnjak S, Jelic S, Susnjar S, Luki V. Gabapentin for relief of neuropathic pain related to anticancer treatment: a preliminary study. J Chemother. 2002; 14:214-219. [PubMed: 12017380]

[19]. Brittain, JM. Program in Medical Neuroscience Vol. Ph.D. Indiana University; 2012. Dual regulation of voltage-and ligand-gated calcium channels by collapsin response mediator protein 2; p. 224

[20]. Brittain JM, Chen L, Wilson SM, Brustovetsky T, Gao X, Ashpole NM, Molosh AI, You H, Hudmon A, Shekhar A, White FA, Zamponi GW, Brustovetsky N, Chen J, Khanna R. Neuroprotection against traumatic brain injury by a peptide derived from the collapsin response mediator protein 2 (CRMP2). The Journal of biological chemistry. 2011; 286:37778-37792. [PubMed: 21832084]

[21]. Brittain JM, Duarte DB, Wilson SM, Zhu W, Ballard C, Johnson PL, Liu N, Xiong W, Ripsch MS, Wang Y, Fehrenbacher JC, Fitz SD, Khanna M, Park CK, Schmutzler BS, Cheon BM, Due MR, Brustovetsky T, Ashpole NM, Hudmon A, Meroueh SO, Hingtgen CM, Brustovetsky N, Ji RR, Hurley JH, Jin X, Shekhar A, Xu XM, Oxford GS, Vasko MR, White FA, Khanna R. Suppression of inflammatory and neuropathic pain by uncoupling CRMP-2 from the presynaptic $\mathrm{Ca}(2)(+)$ channel complex. Nature medicine. 2011; 17:822-829.

[22]. Brittain JM, Piekarz AD, Wang Y, Kondo T, Cummins TR, Khanna R. An atypical role for collapsin response mediator protein 2 (CRMP-2) in neurotransmitter release via interaction with presynaptic voltage-gated calcium channels. The Journal of biological chemistry. 2009; 284:31375-31390. [PubMed: 19755421] 
[23]. Brittain JM, Wang Y, Eruvwetere O, Khanna R. Cdk5-mediated phosphorylation of CRMP-2 enhances its interaction with CaV2.2. FEBS letters. 2012; 586:3813-3818. [PubMed: 23022559]

[24]. Bruckdorfer T, Marder O, Albericio F. From production of peptides in milligram amounts for research to multi-tons quantities for drugs of the future. Curr Pharm Biotechno. 2004; 5:29-43.

[25]. Bucci G, Mochida S, Stephens GJ. Inhibition of synaptic transmission and G protein modulation by synthetic $\mathrm{CaV} 2.2 \mathrm{Ca}(2)+$ channel peptides. The Journal of physiology. 2011; 589:3085-3101. [PubMed: 21521766]

[26]. Bucci, G.; Mochida, S.; Stephens, GJ. Use of Synthetic Ca2+ Channel Peptidesto Study Presynaptic Function. In: Stephens, GJ.; Mochida, S., editors. Modulation of Presynaptic Calcium Channels. Springer ScienceCBusiness Media Dordrecht; Germany: 2013. p. 223-240.

[27]. Buchwald P. Small-molecule protein-protein interaction inhibitors: therapeutic potential in light of molecular size, chemical space, and ligand binding efficiency considerations. IUBMB life. 2010; 62:724-731. [PubMed: 20979208]

[28]. Catterall, W.; Sheng, Z-H. Methods and compositions for screening for presynaptic calcium channel blockers. USA: 1996.

[29]. Catterall WA. Signaling complexes of voltage-gated sodium and calcium channels. Neuroscience letters. 2010; 486:107-116. [PubMed: 20816922]

[30]. Catterall WA. Voltage-gated calcium channels. Cold Spring Harbor perspectives in biology. 2011; 3 a003947.

[31]. Catterall WA, Few AP. Calcium channel regulation and presynaptic plasticity. Neuron. 2008; 59:882-901. [PubMed: 18817729]

[32]. Chi XX, Schmutzler BS, Brittain JM, Hingtgen CM, Nicol GD, Khanna R. Regulation of N-type voltage-gated calcium (CaV2.2) channels and transmitter release by collapsin response mediator protein-2 (CRMP-2) in sensory neurons. J.Cell Sci. 2009; 23:4351-4362. [PubMed: 19903690]

[33]. Chong MS, Hester J. Diabetic painful neuropathy: current and future treatment options. Drugs. 2007; 67:569-585. [PubMed: 17352515]

[34]. Cizkova D, Marsala J, Lukacova N, Marsala M, Jergova S, Orendacova J, Yaksh TL. Localization of $\mathrm{N}$-type $\mathrm{Ca} 2+$ channels in the rat spinal cord following chronic constrictive nerve injury. Exp.Brain Res. 2002; 147:456-463. [PubMed: 12444477]

[35]. Davies JN, Zamponi GW. Old proteinsdeveloping roles: The regulation of calcium channels by synaptic proteins. Channels (Austin). 2008; 2:130-138. [PubMed: 18849653]

[36]. Dib-Hajj SD, Binshtok AM, Cummins TR, Jarvis MF, Samad T, Zimmermann K. Voltage-gated sodium channels in pain states: role in pathophysiology and targets for treatment. Brain Res.Rev. 2009; 60:65-83. [PubMed: 19150627]

[37]. Dib-Hajj SD, Cummins TR, Black JA, Waxman SG. Sodium channels in normal and pathological pain. Annu.Rev.Neurosci. 2010; 33:325-47. 325-347. [PubMed: 20367448]

[38]. Doggrell SA. Intrathecal ziconotide for refractory pain. Expert opinion on investigational drugs. 2004; 13:875-877. [PubMed: 15212625]

[39]. Dolphin AC. Calcium channel auxiliary alpha2delta and beta subunits: trafficking and one step beyond, Nature reviews. Neuroscience. 2012; 13:542-555. [PubMed: 22805911]

[40]. Duchardt F, Fotin-Mleczek M, Schwarz H, Fischer R, Brock R. A comprehensive model for the cellular uptake of cationic cell-penetrating peptides. Traffic. 2007; 8:848-866. [PubMed: 17587406]

[41]. Eroglu C, Allen NJ, Susman MW, O’Rourke NA, Park CY, Ozkan E, Chakraborty C, Mulinyawe SB, Annis DS, Huberman AD, Green EM, Lawler J, Dolmetsch R, Garcia KC, Smith SJ, Luo ZD, Rosenthal A, Mosher DF, Barres BA. Gabapentin receptor alpha2delta-1 is a neuronal thrombospondin receptor responsible for excitatory CNS synaptogenesis. Cell. 2009; 139:380 392. [PubMed: 19818485]

[42]. Feng ZP, Doering CJ, Winkfein RJ, Beedle AM, Spafford JD, Zamponi GW. Determinants of inhibition of transiently expressed voltage-gated calcium channels by omega-conotoxins GVIA and MVIIA. The Journal of biological chemistry. 2003; 278:20171-20178. [PubMed: 12654924]

[43]. Fuchs SM, Raines RT. Pathway for polyarginine entry into mammalian cells. Biochemistry. 2004; 43:2438-2444. [PubMed: 14992581] 
[44]. Fuller JC, Burgoyne NJ, Jackson RM. Predicting druggable binding sites at the protein-protein interface. Drug discovery today. 2009; 14:155-161. [PubMed: 19041415]

[45]. Gorson KC, Schott C, Herman R, Ropper AH, Rand WM. Gabapentin in the treatment of painful diabetic neuropathy: a placebo controlled, double blind, crossover trial. Journal of neurology, neurosurgery, and psychiatry. 1999; 66:251-252.

[46]. Gruner W, Silva LR. Omega-conotoxin sensitivity and presynaptic inhibition of glutamatergic sensory neurotransmission in vitro. J.Neurosci. 1994; 14:2800-2808. [PubMed: 7910202]

[47]. Hatakeyama S, Wakamori M, Ino M, Miyamoto N, Takahashi E, Yoshinaga T, Sawada K, Imoto K, Tanaka I, Yoshizawa T, Nishizawa Y, Mori Y, Niidome T, Shoji S. Differential nociceptive responses in mice lacking the alpha(1B) subunit of $\mathrm{N}$-type $\mathrm{Ca}(2+)$ channels. Neuroreport. 2001; 12:2423-2427. [PubMed: 11496122]

[48]. Hruby VJ. Designing peptide receptor agonists and antagonists. Nat Rev Drug Discov. 2002; 1:847-858. [PubMed: 12415245]

[49]. Hummel G, Reineke U, Reimer U. Translating peptides into small molecules. Molecular BioSystems. 2006; 2:499-508. [PubMed: 17216031]

[50]. C. Institute of Medicine Report from the Committee on Advancing Pain Research, Education, Relieving Pain in America, A Blueprint for Transforming Prevention, Care, Education and Research. The National Academies Press; 2011.

[51]. Ju W, Li Q, Allette YM, Ripsch MS, White FA, Khanna R. Suppression of pain-related behavior in two distinct rodent models of peripheral neuropathy by a homopolyarginine-conjugated CRMP2 peptide. Journal of neurochemistry. 2012; 124:869-879. [PubMed: 23106100]

[52]. Ju W, Li Q, Wilson SM, Brittain JM, Meroueh L, Khanna R. SUMOylation alters CRMP2 regulation of calcium influx in sensory neurons. Channels. 2013; 3

[53]. Ketz AK. Pain management in the traumatic amputee. Critical care nursing clinics of North America. 2008; 20:51-57. [PubMed: 18206584]

[54]. Khanna R, Zougman A, Stanley EF. A proteomic screen for presynaptic terminal N-type calcium channel (CaV2.2) binding partners. Journal of biochemistry and molecular biology. 2007; 40:302-314. [PubMed: 17562281]

[55]. Kim C, Jeon D, Kim YH, Lee CJ, Kim H, Shin HS. Deletion of N-type Ca2+ channel Cav2.2 results in hyperaggressive behaviors in mice. J.Biol.Chem. 2008

[56]. Kim C, Jun K, Lee T, Kim SS, McEnery MW, Chin H, Kim HL, Park JM, Kim DK, Jung SJ, Kim J, Shin HS. Altered nociceptive response in mice deficient in the alpha(1B) subunit of the voltage-dependent calcium channel. Mol.Cell Neurosci. 2001; 18:235-245. [PubMed: 11520183]

[57]. Kisilevsky AE, Zamponi GW. Presynaptic calcium channels: structure, regulators, and blockers. Handbook of experimental pharmacology. 2008:45-75. [PubMed: 18064411]

[58]. Kolosov A, Aurini L, Williams ED, Cooke I, Goodchild CS. Intravenous injection of leconotide, an omega conotoxin: synergistic antihyperalgesic effects with morphine in a rat model of bone cancer pain. Pain Med. 2011; 12:923-941. [PubMed: 21539704]

[59]. Kolosov A, Goodchild CS, Cooke I. CNSB004 (Leconotide) causes antihyperalgesia without side effects when given intravenously: a comparison with ziconotide in a rat model of diabetic neuropathic pain. Pain Med. 2010; 11:262-273. [PubMed: 20002322]

[60]. Lax R. The Future of Peptide Development in the Pharmaceutical Industry. Pharmaufacturing: The International Peptide Review. 2010:10-15.

[61]. Maggi CA, Patacchini R, Santicioli P, Lippe IT, Giuliani S, Geppetti P, Del Bianco E, Selleri S, Meli A. The effect of omega conotoxin GVIA, a peptide modulator of the N-type voltage sensitive calcium channels, on motor responses produced by activation of efferent and sensory nerves in mammalian smooth muscle. Naunyn-Schmiedeberg's archives of pharmacology. 1988; 338:107-113.

[62]. Maier C, Gockel HH, Gruhn K, Krumova EK, Edel MA. Increased risk of suicide under intrathecal ziconotide treatment? - a warning. Pain. 2011; 152:235-237. [PubMed: 21041028]

[63]. Majava V, Loytynoja N, Chen WQ, Lubec G, Kursula P. Crystal and solution structure, stability and post-translational modifications of collapsin response mediator protein 2. FEBS J. 2008; 275:4583-4596. [PubMed: 18699782] 
[64]. McGregor DP. Discovering and improving novel peptide therapeutics. Curr Opin Pharmacol. 2008; 8:616-619. [PubMed: 18602024]

[65]. Mitchell DJ, Kim DT, Steinman L, Fathman CG, Rothbard JB. Polyarginine enters cells more efficiently than other polycationic homopolymers. J Pept.Res. 2000; 56:318-325. [PubMed: 11095185]

[66]. Mochida S, Sheng ZH, Baker C, Kobayashi H, Catterall WA. Inhibition of neurotransmission by peptides containing the synaptic protein interaction site of N-type Ca2+ channels. Neuron. 1996; 17:781-788. [PubMed: 8893034]

[67]. Moore RA, Wiffen PJ, Derry S, McQuay HJ. Gabapentin for chronic neuropathic pain and fibromyalgia in adults. Cochrane Database Syst Rev. 2011 CD007938.

[68]. Morello CM, Leckband SG, Stoner CP, Moorhouse DF, Sahagian GA. Randomized double-blind study comparing the efficacy of gabapentin with amitriptyline on diabetic peripheral neuropathy pain. Archives of internal medicine. 1999; 159:1931-1937. [PubMed: 10493324]

[69]. Muller CS, Haupt A, Bildl W, Schindler J, Knaus HG, Meissner M, Rammner B, Striessnig J, Flockerzi V, Fakler B, Schulte U. Quantitative proteomics of the Cav2 channel nanoenvironments in the mammalian brain. Proceedings of the National Academy of Sciences of the United States of America. 2010; 107:14950-14957. [PubMed: 20668236]

[70]. Newman DJ, Cragg GM. Natural Products As Sources of New Drugs over the 30 Years from 1981 to 2010. J Nat Prod. 2012; 75:311-335. [PubMed: 22316239]

[71]. Nikolajsen L, Finnerup NB, Kramp S, Vimtrup AS, Keller J, Jensen TS. A randomized study of the effects of gabapentin on postamputation pain. Anesthesiology. 2006; 105:1008-1015. [PubMed: 17065896]

[72]. Pajouhesh H, Feng ZP, Ding Y, Zhang L, Pajouhesh H, Morrison JL, Belardetti F, Tringham E, Simonson E, Vanderah TW, Porreca F, Zamponi GW, Mitscher LA, Snutch TP. Structureactivity relationships of diphenylpiperazine N-type calcium channel inhibitors. Bioorganic \& medicinal chemistry letters. 2010; 20:1378-1383. [PubMed: 20117000]

[73]. Pajouhesh H, Feng ZP, Zhang L, Pajouhesh H, Jiang X, Hendricson A, Dong H, Tringham E, Ding Y, Vanderah TW, Porreca F, Belardetti F, Zamponi GW, Mitscher LA, Snutch TP. Structure-activity relationships of trimethoxybenzyl piperazine N-type calcium channel inhibitors. Bioorganic \& medicinal chemistry letters. 2012; 22:4153-4158. [PubMed: 22579422]

[74]. Pexton T, Moeller-Bertram T, Schilling JM, Wallace MS. Targeting voltage-gated calcium channels for the treatment of neuropathic pain: a review of drug development. Expert opinion on investigational drugs. 2011; 20:1277-1284. [PubMed: 21740292]

[75]. Piekarz AD, Due MR, Khanna M, Wang B, Ripsch MS, Wang R, Meroueh SO, Vasko MR, White FA, Khanna R. CRMP-2 peptide mediated decrease of high and low voltage-activated calcium channels, attenuation of nociceptor excitability, and anti-nociception in a model of AIDS therapy-induced painful peripheral neuropathy. Molecular pain. 2012; 8:54. [PubMed: 22828369]

[76]. Prommer E. Ziconotide: a new option for refractory pain. Drugs Today (Barc). 2006; 42:369378. [PubMed: 16845440]

[77]. Prommer EE. Ziconotide: can we use it in palliative care? The American journal of hospice \& palliative care. 2005; 22:369-374. [PubMed: 16225359]

[78]. Quach TT, Massicotte G, Belin MF, Honnorat J, Glasper ER, Devries AC, Jakeman LB, Baudry M, Duchemin AM, Kolattukudy PE. CRMP3 is required for hippocampal CA1 dendritic organization and plasticity. FASEB journal : official publication of the Federation of American Societies for Experimental Biology. 2008; 22:401-409. [PubMed: 17785607]

[79]. Rauck RL, Wallace MS, Burton AW, Kapural L, North JM. Intrathecal ziconotide for neuropathic pain: a review. Pain practice : the official journal of World Institute of Pain. 2009; 9:327-337. [PubMed: 19682321]

[80]. Rettig J, Sheng ZH, Kim DK, Hodson CD, Snutch TP, Catterall WA. Isoform-specific interaction of the alpha1A subunits of brain $\mathrm{Ca} 2+$ channels with the presynaptic proteins syntaxin and SNAP-25. Proc.Natl.Acad.Sci.U.S.A. 1996; 93:7363-7368. [PubMed: 8692999]

[81]. Ripsch MS, Ballard CJ, Khanna M, Hurley JH, White FA, Khanna R. A PEPTIDE UNCOUPLING CRMP-2 FROM THE PRESYNAPTIC Ca(2+) CHANNEL COMPLEX DEMONSTRATES EFFICACY IN ANIMAL MODELS OF MIGRAINE AND AIDS 
THERAPY-INDUCED NEUROPATHY. Translational neuroscience. 2012; 3:1-8. [PubMed: 22662308]

[82]. Rowbotham M, Harden N, Stacey B, Bernstein P, Magnus-Miller L. Gabapentin for the treatment of postherpetic neuralgia: a randomized controlled trial. JAMA : the journal of the American Medical Association. 1998; 280:1837-1842. [PubMed: 9846778]

[83]. Rusy LM, Troshynski TJ, Weisman SJ. Gabapentin in phantom limb pain management in children and young adults: report of seven cases. Journal of pain and symptom management. 2001; 21:78-82. [PubMed: 11223317]

[84]. Saegusa H, Kurihara T, Zong S, Kazuno A, Matsuda Y, Nonaka T, Han W, Toriyama H, Tanabe T. Suppression of inflammatory and neuropathic pain symptoms in mice lacking the N-type Ca2+ channel. EMBO J. 2001; 20:2349-2356. [PubMed: 11350923]

[85]. Schmidtko A, Lotsch J, Freynhagen R, Geisslinger G. Ziconotide for treatment of severe chronic pain. Lancet. 2010; 375:1569-1577. [PubMed: 20413151]

[86]. Schroeder CI, Doering CJ, Zamponi GW, Lewis RJ. N-type calcium channel blockers: novel therapeutics for the treatment of pain. Med Chem. 2006; 2:535-543. [PubMed: 17017994]

[87]. Scott DA, Wright CE, Angus JA. Actions of intrathecal omega-conotoxins CVID, GVIA, MVIIA, and morphine in acute and neuropathic pain in the rat. Eur.J.Pharmacol. 2002; 451:279286. \%20. [PubMed: 12242089]

[88]. Serpell MG. Gabapentin in neuropathic pain syndromes: a randomised, double-blind, placebocontrolled trial. Pain. 2002; 99:557-566. [PubMed: 12406532]

[89]. Seward E, Hammond C, Henderson G. Mu-opioid-receptor-mediated inhibition of the N-type calcium-channel current. Proc.Biol.Sci. 1991; 244:129-135. [PubMed: 1679547]

[90]. Sheng ZH, Rettig J, Cook T, Catterall WA. Calcium-dependent interaction of N-type calcium channels with the synaptic core complex. Nature. 1996; 379:451-454. [PubMed: 8559250]

[91]. Sheng ZH, Rettig J, Takahashi M, Catterall WA. Identification of a syntaxin-binding site on Ntype calcium channels. Neuron. 1994; 13:1303-1313. [PubMed: 7993624]

[92]. Skov MJ, Beck JC, de Kater AW, Shopp GM. Nonclinical safety of ziconotide: an intrathecal analgesic of a new pharmaceutical class. International journal of toxicology. 2007; 26:411-421. [PubMed: 17963128]

[93]. Smith MT, Cabot PJ, Ross FB, Robertson AD, Lewis RJ. The novel N-type calcium channel blocker, AM336, produces potent dose-dependent antinociception after intrathecal dosing in rats and inhibits substance P release in rat spinal cord slices. Pain. 2002; 96:119-127. [PubMed: 11932068]

[94]. Snutch TP. Targeting chronic and neuropathic pain: the N-type calcium channel comes of age. NeuroRx. 2005; 2:662-670. [PubMed: 16489373]

[95]. Stanley EF. The calcium channel and the organization of the presynaptic transmitter release face. Trends Neurosci. 1997; 20:404-409. [PubMed: 9292969]

[96]. Stevenson CL. Advances in Peptide Pharmaceuticals. Curr Pharm Biotechno. 2009; 10:122-137.

[97]. Su KY, Chien WL, Fu WM, Yu IS, Huang HP, Huang PH, Lin SR, Shih JY, Lin YL, Hsueh YP, Yang PC, Lin SW. Mice deficient in collapsin response mediator protein-1 exhibit impaired long-term potentiation and impaired spatial learning and memory. J.Neurosci. 2007; 27:25132524. [PubMed: 17344389]

[98]. Swensen AM, Herrington J, Bugianesi RM, Dai G, Haedo RJ, Ratliff KS, Smith MM, Warren VA, Arneric SP, Eduljee C, Parker D, Snutch TP, Hoyt SB, London C, Duffy JL, Kaczorowski GJ, McManus OB. Characterization of the Substituted N-triazole oxindole, TROX-1, a Small Molecule, State-dependent Inhibitor of CaV2 Calcium Channels. Mol.Pharmacol. 2011

[99]. Thompson JC, Dunbar E, Laye RR. Treatment challenges and complications with ziconotide monotherapy in established pump patients. Pain physician. 2006; 9:147-152. [PubMed: 16703976]

[100]. Todorovic SM, Jevtovic-Todorovic V. T-type voltage-gated calcium channels as targets for the development of novel pain therapies. Br.J.Pharmacol. 2011; 163:484-495. [PubMed: 21306582]

[101]. Tunnemann G, Ter-Avetisyan G, Martin RM, Stock1 M, Herrmann A, Cardoso MC. Live-cell analysis of cell penetration ability and toxicity of oligo-arginines. J Pept.Sci. 2008; 14:469-476. [PubMed: 18069724] 
[102]. Turner RW, Anderson D, Zamponi GW. Signaling complexes of voltage-gated calcium channels. Channels (Austin). 2011; 5:440-448. [PubMed: 21832880]

[103]. Udall M, Harnett J, Mardekian J. Costs of pregabalin or gabapentin for painful diabetic peripheral neuropathy. Journal of medical economics. 2012; 15:361-370. [PubMed: 22181052]

[104]. Udall M, Mardekian J, Cabrera J. Identification of Patients with Painful Diabetic Peripheral Neuropathy Who Have a Favorable Cost Profile with Pregabalin Treatment. Pain practice : the official journal of World Institute of Pain. 2012

[105]. Vlieghe P, Lisowski V, Martinez J, Khrestchatisky M. Synthetic therapeutic peptides: science and market. Drug discovery today. 2010; 15:40-56. [PubMed: 19879957]

[106]. Waithe D, Ferron L, Page KM, Chaggar K, Dolphin AC. Beta-subunits promote the expression of $\mathrm{Ca}(\mathrm{V}) 2.2$ channels by reducing their proteasomal degradation. The Journal of biological chemistry. 2011; 286:9598-9611. [PubMed: 21233207]

[107]. Wender PA, Mitchell DJ, Pattabiraman K, Pelkey ET, Steinman L, Rothbard JB. The design, synthesis, and evaluation of molecules that enable or enhance cellular uptake: peptoid molecular transporters. Proc.Natl.Acad.Sci.U.S.A. 2000; 97:13003-13008. [PubMed: 11087855]

[108]. Westenbroek RE, Hell JW, Warner C, Dubel SJ, Snutch TP, Catterall WA. Biochemical properties and subcellular distribution of an N-type calcium channel alpha 1 subunit. Neuron. 1992; 9:1099-1115. [PubMed: 1334419]

[109]. Williams JA, Day M, Heavner JE. Ziconotide: an update and review. Expert opinion on pharmacotherapy. 2008; 9:1575-1583. [PubMed: 18518786]

[110]. Wilson SM, Brittain JM, Piekarz AD, Ballard CJ, Ripsch MS, Cummins TR, Hurley JH, Khanna M, Hammes NM, Samuels BC, White FA, Khanna R. Further insights into the antinociceptive potential of a peptide disrupting the N-type calcium channel-CRMP-2 signaling complex. Channels (Austin). 2011; 5:449-456. [PubMed: 21829088]

[111]. Wilson SM, Schmutzler BS, Brittain JM, Dustrude ET, Ripsch MS, Pellman JJ, Yeum TS, Hurley JH, Hingtgen CM, White FA, Khanna R. Inhibition of Transmitter Release and Attenuation of AIDS Therapy-Induced and Tibial Nerve Injury-Related Painful Peripheral Neuropathy by Novel Synthetic Ca2+ Channel Peptides. The Journal of biological chemistry. 2012; 287:35065-35077. [PubMed: 22891239]

[112]. Woodley JF. Enzymatic Barriers for Gi Peptide and Protein Delivery. Crit Rev Ther Drug. 1994; 11:61-95.

[113]. Yaksh TL. Calcium channels as therapeutic targets in neuropathic pain. J.Pain. 2006; 7:S13S30. [PubMed: 16426997]

[114]. Zamponi GW, Feng ZP, Zhang L, Pajouhesh H, Ding Y, Belardetti F, Pajouhesh H, Dolphin D, Mitscher LA, Snutch TP. Scaffold-based design and synthesis of potent N-type calcium channel blockers. Bioorganic \& medicinal chemistry letters. 2009; 19:6467-6472. [PubMed: 19815411]

[115]. Zamponi GW, Lewis RJ, Todorovic SM, Arneric SP, Snutch TP. Role of voltage-gated calcium channels in ascending pain pathways. Brain research reviews. 2009; 60:84-89. [PubMed: 19162069]

[116]. Zareba G. New treatment options in the management of fibromyalgia: role of pregabalin. Neuropsychiatr.Dis.Treat. 2008; 4:1193-1201. [PubMed: 19337459]

[117]. Zompra AA, Galanis AS, Werbitzky O, Albericio F. Manufacturing peptides as active pharmaceutical ingredients. Future medicinal chemistry. 2009; 1:361-377. [PubMed: 21425973] 


\section{Highlights}

- $\mathrm{CaV} 2.2$ calcium channels are a prime target for development of novel analgesics

- Targeting CaV2.2 complex proteins may avoid side-effects of CaV2.2-targeted drug

- Axonal growth protein CRMP2 interacts with and regulates function of CaV2.2

- CRMP2 peptide is anti-nociceptive in models of neuropathic pain

- Tailored CRMP2 peptides hold promise for next generation analgesics 

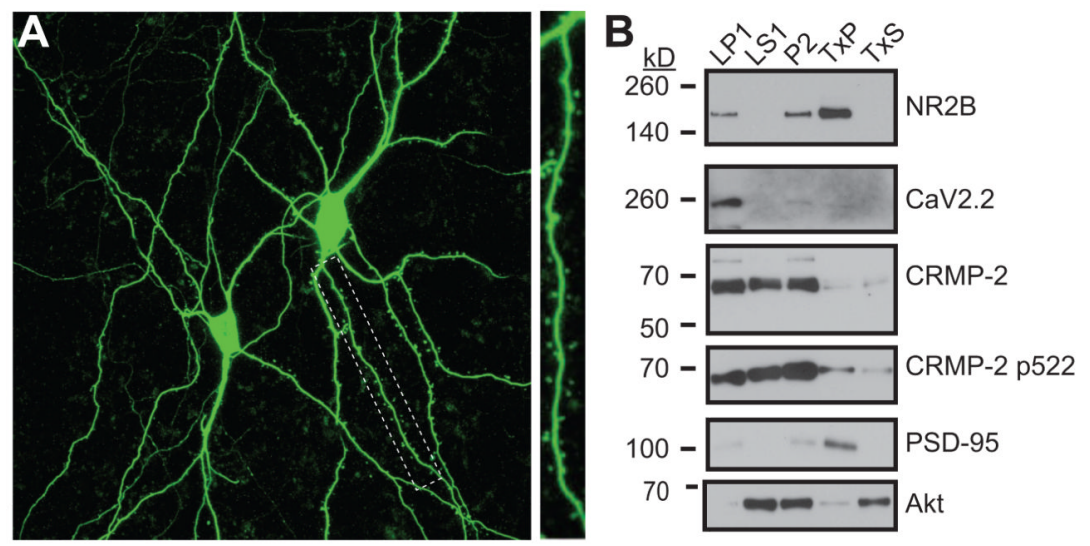

Figure 1. CRMP2 localization

(A) Representative pseudo-colored image of two CRMP-2-EGFP transfected hippocampal neurons in organotypic slice cultures 5 days post transfection. The expanded region shows a primary dendrite with robust expression in spines. Image provided by Dr. Xiaoming Jin. (B) Synaptic and extra-synaptic fractions from postnatal day 1 rats were isolated using differential centrifugation and detergent selective sedimentation and immunoblotted with antibodies as indicated. The post-synaptic density fraction (PSD) is insoluble in Triton X-100 and was used to separate synaptic (Triton X-100 insoluble pellet, TxP in which the proteins PSD-95 and the NMDAR are abundant) from extra-synaptic fractions (Triton X-100 soluble, TxS). Fractions and percent loaded were: LP1 (0.8\%), intracellular membranes; LS1 (0.1\%) cytosol non-membrane; P2 (0.3\%) synaptosomes; TxP (1.2\%) synaptic fraction; and TxS $(0.4 \%)$ extra-synaptic. Molecular weight markers are indicated in kilodaltons $(\mathrm{kD})$. Data are reproduced from the doctoral work of Dr. Brittain in the Khanna laboratory [19]. 

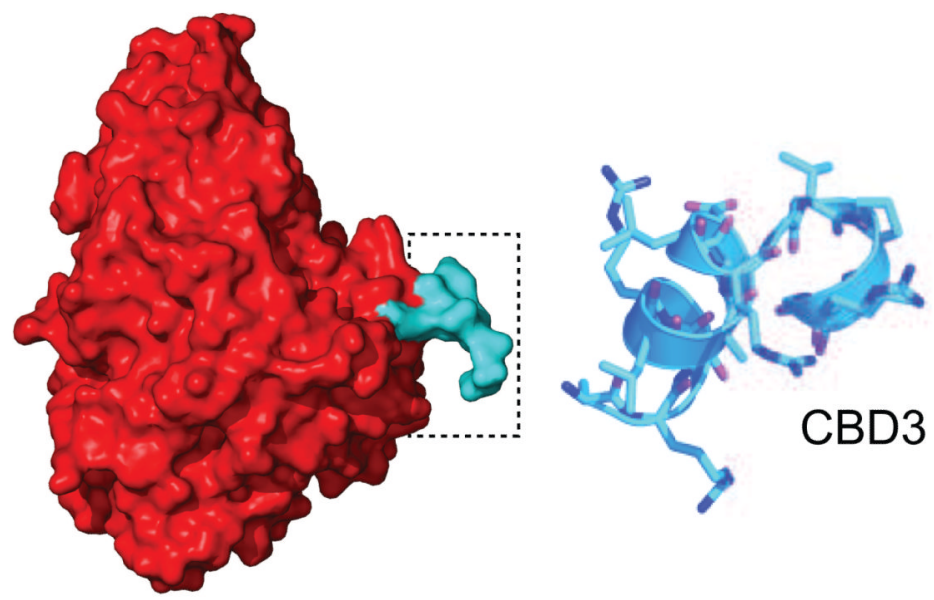

Figure 2. CRMP2 structure and CBD3 model

Crystal structure of momomeric CRMP2 [63]. As the CRMP2 structure is truncated at amino at 490, only 6 of the fifteen amino acids that comprise CBD3 are present in this structure. These 6 amino acids are shown in the boxed region in the crustal structure. A model of the entire fifteen amino acid CBD3 peptide [75] is shown in blue illustrating the plastic nature of the amino-terminal residues. 


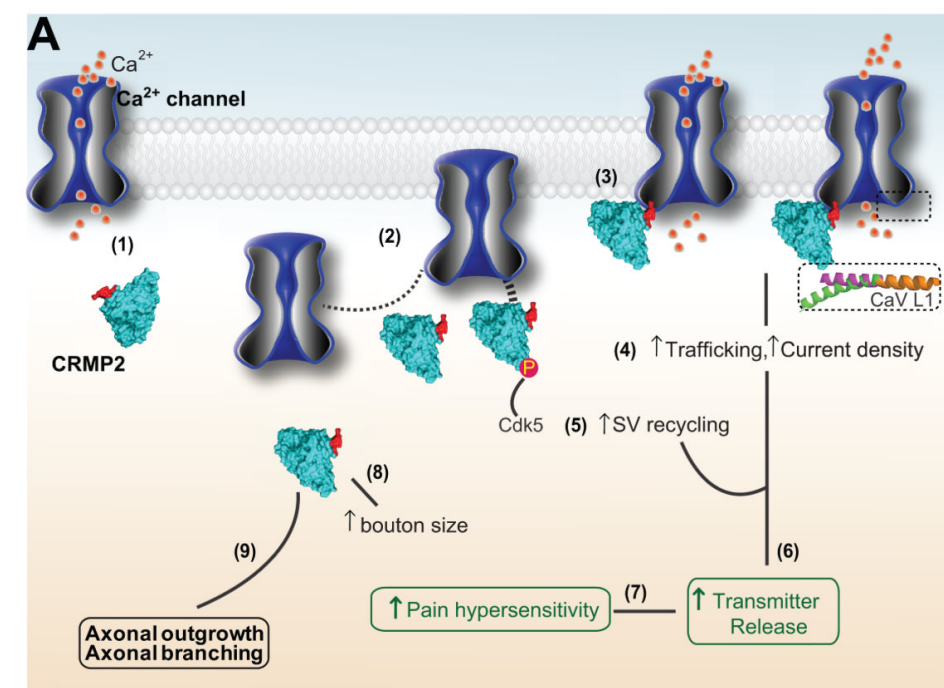

B

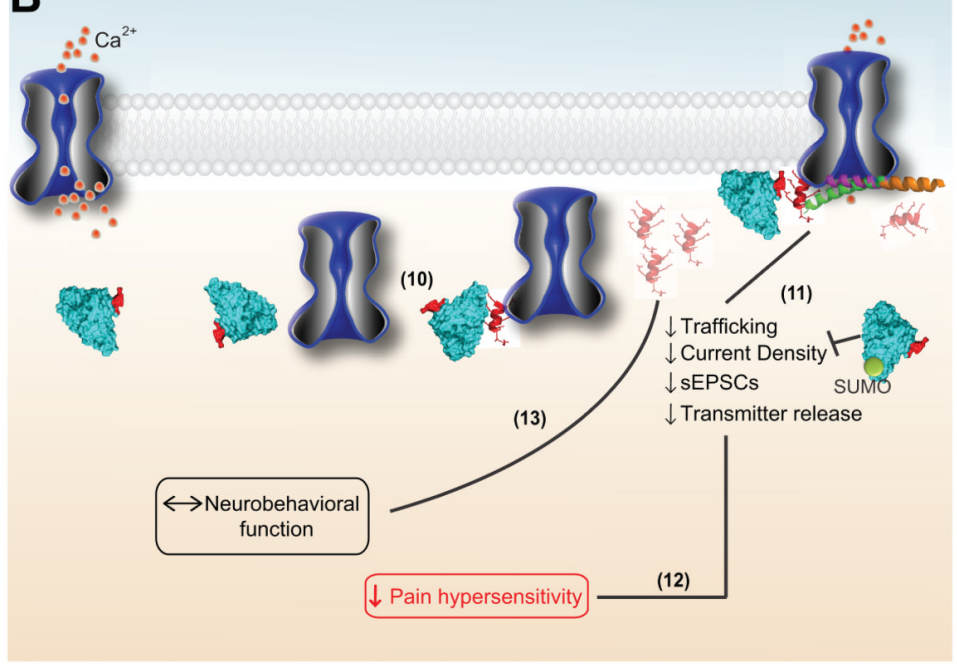

Figure 3. Targeting CRMP2/CaV2.2 interaction

(A) Functional consequences of CRMP2/CaV2.2 interaction. The cytosolic protein CRMP2 (1) interacts with the N-type calcium channel (2), increasing forward trafficking of CaV2.2 to the membrane (3). Phosphorylation of CRMP2 by the priming kinase cyclin dependent kinase 5 (Cdk5) increases the interaction between CRMP2 and CaV2.2 [23]. The increased surface expression directly correlates with increased calcium current density (4). Along with increased synaptic vesicle recycling (5), the increase in current density leads to a subsequent increase in neurotransmitter release (6) and, potentially, pain hypersensitivity (7).

Additionally, CRMP-2 overexpression increases the average size of synaptic boutons (8), which may be attributed to its native functions in axonal outgrowth and branching (9). (B) TAT-CBD3 effectively blocks the interaction between CRMP-2 and CaV2.2 (10), leading to decreased membrane trafficking, current density, spontaneous EPSCs (sEPCs), and neurotransmitter release (11). Recent evidence suggests that post-translational modification of CRMP2 by the small ubiquitin-like modifier (SUMO) has a negative impact on calcium influx in sensory neurons [52]. The functional consequences of TAT-CBD3 treatment resulted in an overall decrease in pain hypersensitivity (12). Single doses of TAT-CBD3 have not demonstrated deleterious effects on neurobehavioral and sympathetic function (13). 
Similar mechanistic effects on trafficking and overall in vivo effects on relief of chronic pain are observed with a peptide (structure shown [7]) from the calcium channel itself [111]. 

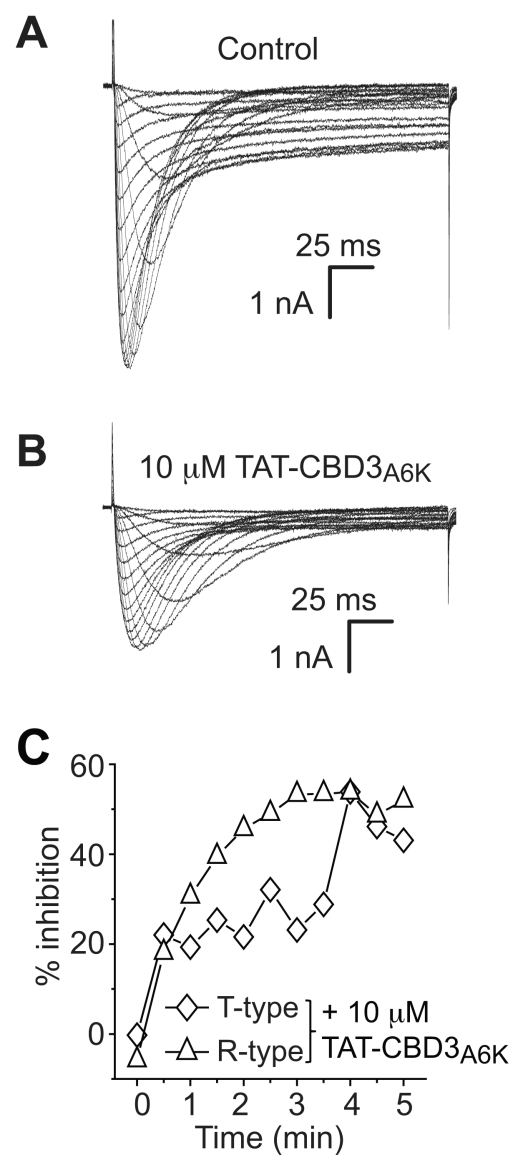

Figure 4. Effects of TAT-CBD3A6K on T- and R-type calcium currents in sensory neurons Representative family of traces from a DRG neuron with both T- and R-type calcium currents before (A) and $5 \mathrm{~min}(\mathbf{B})$ after addition of $10 \mu \mathrm{M}$ TAT-CBD3A6K. Currents were elicited in response to the $200 \mathrm{~ms}$ steps in $5 \mathrm{mV}$ increments from $-60 \mathrm{mV}$ to $+50 \mathrm{mV}$, from a holding potential of $-90 \mathrm{mV}$. To isolate T- and R-type calcium currents, the extracellular bath solution contained $5 \mathrm{mM}$ Nifedipine (Nif), $200 \mathrm{nM} \omega$-Agatoxin IVA (Aga) and $500 \mathrm{nM}$ $\omega$-Conotoxin GVIA (CTX) to block L-, P/Q-, and N-type calcium currents, respectively. At $-10 \mathrm{mV}$, T-type calcium currents contribute to $>80 \%$ of the conductance with R-type contributing $<3 \%$. Time course of TAT-CBD3A6K mediated inhibition of T-type and Rtype $(\mathbf{C})$ calcium currents. Time course of inhibition is shown as averaged normalized current density $\left(\mathrm{pA} \mathrm{pF}^{-1}\right)$ before peptide addition and at intervals of $30 \mathrm{~s}$ for $5 \mathrm{~min}$. Averaged values are shown with standard error for 4-6 control cells and 4 cells following addition of $10 \mu \mathrm{M}$ TAT-CBD3A6K. Some error bars are smaller than the symbols. Data represent mean \pm SEM from $n=3-6$ cells at each time point except for $n=2$ the 4 min time point for T-type currents in the presence of peptide. 


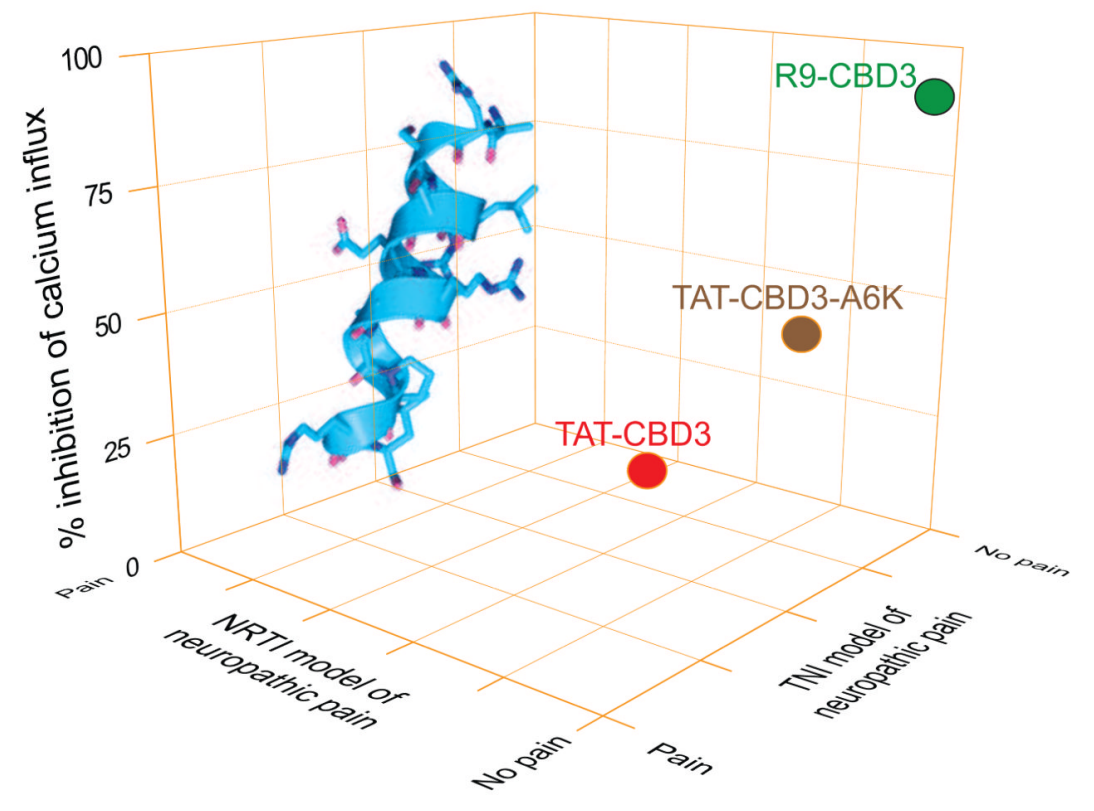

Figure 5. Tuning CBD3

Graph illustrating optimization of CBD3 with a single point mutant (A6K) or use of the nona-arginine cell-penetrating motif. The relative efficacy of each peptide in blocking depolarization-evoked calcium influx is shown. The efficacy of systemically administered peptides in the nucleoside reverse transcriptase inhibitor (NRTI)- or tibial nerve injury (TNI)-induced pain models is also shown. 